Federico M. Federici, Christophe Declercq (eds)

\title{
Intercultural Crisis Communication: \\ Translation, Interpreting and Languages in Local Crises
}

\author{
(London, Bloomsbury Academic, 2020. xi + 268 pp. \\ ISBN: 978-1-3500-9705-6) \\ Bánhegyi Mátyás \\ E-mail:banhegyi.matyas@uni-bge.hu
}

Az elmúlt évtizedekben a fordítástudomány behatóan foglalkozott a globális és nemzetközi konfliktusok, valamint az azokról szóló narratívák és fordításaik leírásával, jellemzésével. Az utóbbi időben e téren sok olyan kutatás látott napvilágot, amely a nem szövegbeli jellemzőket vizsgálta, céljaira pedig etnográfiai módszereket alkalmazott politikailag kényes vagy éppen eröszakba torkolló nemzetközi, illetve országok közötti események és a nyelvek közötti kommunikáció leírásakor. Konfliktusokra és krízishelyzetekre összpontosítva, továbbá a fenti kutatási trendekbe illeszkedve, az ebben a cikkben recenzált Intercultural Crisis Communication címü tanulmánykötet a nyelvi mediációt (közvetítést) vizsgálja humanitáriánus, migrációval összefüggő és politikai szükséghelyzetek, valamint természeti és környezeti katasztrófák és kommunikációjuk kapcsán.

A kötet - illeszkedve a fordítástudományt jelenleg jellemző interkulturális áramlatba - interdiszciplináris megközelítéssel kutatja a krízishelyzetek során megvalósuló és a krízishelyzetekről szóló kommunikációt. A könyv szerkesztőiként jegyzett és e kutatási terület nemzetközileg elismert szaktekintélyei, a University College London egyetemi docense, Federico M. Federici és a University College London adjunktusaként és a Leuveni Katolikus Egyetem óraadójaként dolgozó Christophe Declercq a kötetben egy új területet, a kríziskommunikációt és annak fordítástudománnyal összefüggő területeit veszik górcső alá. Az olvasókat francia-, olasz-, horvát-, spanyol-, örmény- és görögországbeli események kapcsán ismertetik meg olyan kríziskommunikációs helyzetekkel, amelyekben kevéssé használt vagy kisebbségi nyelvek érintettek. E menekültek támogatását, az ehhez kapcsolódó egészségügyi segítségnyújtást és tömegek számára negatív követ-

Hivatkozás: Bánhegyi M. 2020. Federico M. Federici, Christophe Declercq (eds) Intercultural Crisis Communication: Translation, Interpreting and Languages in Local Crises. Forditástudomány 22. évf. 2. szám. 128-136.

DOI: https://doi.org/10.35924/fordtud.22.2.10. 
kezményeket magukban foglaló események során elöálló fordítási helyzeteket esettanulmányok, helyszíni terepmunka vagy korpuszalapú kutatások révén tárják fel a szerzők.

A tanulmányok társadalmi és történelmi - és ebből kifolyólag fordítástudományi - hátterét globális vagy helyi, de mindenképpen határokon átívelö krízishelyzetek adják, amely esetén többnyelvü kommunikációt figyelhetünk meg: ez egyrészt az adott helyzetben keletkezik, másrészt az adott helyzetröl szól. Ezek a nemzetek és etnikai csoportok feletti, nemzetközi vagy éppen globális vészhelyzetek és katasztrófák különbözö kiterjedésüek lehetnek, az érintettek között egyedülálló személyeket, egész családokat, társadalmi csoportokat, vallásokat, országokat, nemzeteket és etnikai csoportokat egyaránt találunk. E szituációk közös jellemzője, hogy a kommunikáció nemcsak soknyelvü környezetben történik, hanem az érintettek és a nyilvánosság közötti interkulturális interakciót is magában foglal, ami kifejezetten érdekes fordítástudományi vizsgálódások talajává teszi e területet. A kiadvánnyal a szerzők - többek között - vélhetőleg éppen az ilyen jellegü helyzetek és területek vizsgálatára, illetve az ilyen típusú kutatások létjogosultságára és szükségességére kívánják felhívni a szakma figyelmét.

A tanulmánykötet három tematikus részre oszlik, amelyek hasonló témájuknak és megközelítésüknek köszönhetően egymással is dialogikus kapcsolatban állnak. Az első részben található négy cikk a menekültek számára nyújtott nyelvi mediáció témájával foglalkozik, a második rész négy tanulmánya az egészségügy területéhez kötődik, míg a harmadik rész három cikke helyi krízishelyzetek nemzetközi szintü nyelvi megjelenítésével foglalkozik. Az alábbiakban részenként haladva röviden ismertetjük az egyes tanulmányokat.

Az első rész Stefania Taviano által írt első tanulmánya (címe: The Counternarratives of Migrants and Cultural Mediators) a nyelvhasználat, a fordítás és a tolmácsolás kérdéseit feszegeti az Olaszországba érkező migránsok kapcsán: a kommunikációs résztvevők közötti olyan egyenlőtlen vagy méltánytalanságot hordozó helyzeteket vizsgál, amelyekben kulturális mediátorok is dolgoznak. A cikk különbséget tesz a jelenleg kevésbé pontosan definiált kulturális mediátorok, valamint a fordítók és (közösségi) tolmácsok munkája között és megállapítja, hogy e tevékenységek közötti választóvonal nem mindig egyértelmü. A tanulmány - Taronna (2015) kutatásaira támaszkodva - a kulturális mediátorokat olyan személyeknek írja le, akik határokon átívelö, aktivista tevékenységükkel és az általuk nyújtott fordítási és kulturális mediációs munkával hozzájárulnak az állampolgárság mint fogalom és a határokon átívelő állampolgárság újraértelmezéséhez.

A cikk két mediátorról közöl esettanulmányt és ennek kapcsán bepillantást enged abba, hogy hogyan alakul, illetve változik a migránsok identitása fordítás és kulturális mediáció révén. Az egyik mediátor a migráns kulturális hátteréből jön, a másik pedig a befogadó kultúrából: kettejük nyelvhasználata és hozzáállása különbözö, kommunikációjuk hatékonysága pedig függ a nyelvi és kulturális különbségek ismeretének mélységétől. Munkája során mind a két mediátor ellenáll a befogadó kultúra nyomásának: kulturális téren oly módon segítik a menekülők 
beilleszkedését, hogy a befogadó kultúra számára magyarázattal szolgálnak a migránsoknak a befogadó kultúra szemében furcsa, váratlan vagy éppen elfogadhatatlan magatartásáról, így jelentésalku (meaning negotiation) segítségével járulnak hozzá a menekülők állampolgárságának és identitásának kialakításához. Egyebek mellett a cikk síkra száll azért is, hogy a jó minőségü fordítás mint szükséges elem jelenjen meg az emberi és munkavállalói jogokról szóló diskurzusban és az ilyen típusú ügyek intézése terén.

Az első rész második cikke Vedrana Čemerin tollából (Language Mediation in Emergency Migration Contexts: A Case Study of the Migrant Crisis 2015 in Croatia címmel) a horvátországi menekültkrízis idején vizsgálja a nyelvközi fordítást és tolmácsolást, azaz az olyan helyzeteket, ahol a két kommunikációs résztvevő közé egy nyelvi (és kulturális) közvetítő ékelődik. A korabeli újságcikkeket és egyéb írásos dokumentumokat feldolgozó, valamint etnográfiai módszerrel készült, félig strukturált interjúkat használó kvalitatív módszertanú tanulmány a nyelvi közvetítés és a kríziskommunikáció szerepét vizsgálja a fent említett, 2015-ös események során.

A humanitáriánus krízishelyzet idején a ritka vagy még teljesen ki nem alakult nyelveket beszélő menekülteknek orvosi és pszichológiai segítségre volt szükségük, amelyet nagyban hátráltatott az, hogy egyrészről a migránsok, másrészről pedig az őket támogató orvosi és egyéb személyzet, illetve a hatóságok között nyelvi korlát alakult ki. A helyzet megoldására képzett tolmácsokat kerestek, ám azok hiányában a migránsok kulturális hátteréből családi kötelékekkel rendelkezö, szakképzetlen horvát anyanyelvi beszélőket voltak be a munkába, akik a menekültekkel azok anyanyelvén tudtak kommunikálni.

A cikkböl megtudjuk, hogy - egyebek mellett - nyelvi szempontból hogyan müködtek a menekültügyi befogadóállomások: az írásos kommunikáció helyett föként a jóval hatékonyabbnak bizonyuló szóbeli kommunikációt használták, az pedig vagy személyesen vagy pedig hangos bemondó segítségével zajlott. A munka során tolmácsolási segéd- és háttéranyagként egy bárki által szabadon szerkeszthető és használható, többnyelvű kifejezésszótárt fejlesztettek ki. Végkövetkeztetésként Čemerin azt javasolja, hogy a már meglévő szakirodalom és a bevált, jó gyakorlatok felhasználásával készüljön szakmai útmutató az ilyen helyzetben alkalmazott nyelvi mediációról, amelyet később oktatási segédanyagként is lehetne használni.

A harmadik tanulmány (címe: The Role of the Translator and Interpreter in Terrorist Conflicts) a terrorizmus elleni küzdelem részeként a nyelvi közvetítök képzését sürgeti. Carmen Pena-Díaz konfliktusok sújtotta övezetek viszonylatában a fordítók és tolmácsok szerepét elemzi olyan szempontból, hogy ezek a nyelvi közvetítők hogyan járulhatnak hozzá a nemzetközi terrorizmus megakadályozásához és a békefolyamatok elősegítéséhez. A cikk két alapvetésből indul ki: a) a fordítás a civil lakosság számára képes védelmet és biztonságot nyújtani, amenynyiben „kommunikációs eszközként” megfelelően használják, valamint b) terrorizmus által elöidézett krízishelyzetekben a hatékony kommunikáció - amelynek része a fordítás is - a helyzet pontos megértéséhez, valamint a szituációban szükséges információk és irányelvek terjesztéséhez elengedhetetlen. A narratív elmé- 
letre, amely szerint az uralkodó narratíva, történetek és események alapvetően meghatározzák az emberi magatartást, és annak a Mona Baker-féle $(2006,2010)$ fordítástudományi adaptációjára támaszkodva a szerző úgy véli, a fordítóknak egyegy szöveg háttér-információival is tisztában kell lenniük és mediációs tevékenységet is kell folytatniuk, ha a konfliktusokat megakadályozó társadalmi párbeszédet fenn akarják tartani.

A cikk a fordítók ilyen jellegü tevékenységének alaposabb feltárása céljából arra a kérdésre kíván válaszolni, hogy milyen fordítói szerepek szükségesek e munka sikeréhez, ezt pedig spanyolországi kormányzati szervektől és nemzeti intézményektől származó adatgyüjtés és példák alapján vizsgálja. A konklúzióban a szerző kifejti, hogy a (politikai) konfliktusok sikeres kezeléséhez speciális felkészítésben részesülő szakértők szükségesek, akiknek a konfliktuszónákhoz kapcsolódó etnikai háttérből kell érkezniük, valamint olyan nemzetek és régiók kultúráiról, történelméről, politikai és gazdasági vonatkozásairól kell szaktudással rendelkezniük, amelyek az őket foglalkoztató országnak, szervezetnek, közösségnek stratégiailag fontosak.

Az első rész negyedik tanulmányában (Language, Culture and Perceived Ethnic Homeland Integration: Syrian Armenian Forced Migrants in Armenia címmel) Daria Vorobyeva Szíriából származó menekültek örményországi integrációját taglalja nyelvi és kulturális szempontból. E kérdést négy szemszögböl elemzi: nyelv, integráció, valamint kulturális és pszichológiai tényezők. A cikk - tekintettel az olvasók vélhetőleg kevésbé alapos háttértudására - érinti a szíriai örmények történelmét, valamint az örményországi orosz befolyás nyelvi és kulturális hatásának kérdését. A szerző 2015-ben empirikus vizsgálódásainak részeként terepmunkát végzett Örményországban, ahol 1) a nyelv szerepét elemezte a szíriai örmények örményországbeli társadalmi és gazdasági integrációját illetően és 2) felmérte a szíriai örmények integrációjának kulturális és pszichológiai tényezőit. A tanulmány megállapításai szerint a nyelvismeret hozzájárul a betelepülők foglalkoztathatóságának növeléséhez és a közintézmények által nyújtott szolgáltatások igénybevételéhez, valamint ahhoz, hogy a betelepülök sikeresen tudjanak társadalmi kapcsolatokat kiépíteni az ott élökkel, amit amúgy is hátráltat az, hogy az örményországi standard nyelv és a szíriai örmények által beszélt nyelvváltozat egymáshoz képest számos különbséget hordoz.

A második rész első tanulmánya Vicent Montalt Resurreccio tollából (Medical Translation in Crisis Situations címen) - szakítva a korábbi gyakorlattal, hogy az orvosi szövegek fordítása kizárólag az egészségügyi intézmények megszokott és ismert szolgáltatási skálájához és helyzeteihez kötődhet - azt vizsgálja, hogy krízishelyzetekben milyen tipikus jellemzői vannak az egészségügyi kommunikációnak, hogy mit tanulhatunk az orvosi szövegek fordítása kapcsán a krízishelyzetekből és hogy a fordítás hogyan javíthatja a krízisek idején történő kommunikációt. A krízishelyzetek alatti orvosi kommunikációt alapvetően meghatározza az, hogy ez a helyzet számos szereplőt érint, valamint hogy az áldozatok, illetve betegek emocionális hatás alatt vannak, és a saját anyanyelvükön kívánnak kommunikálni. 
A tanulmányban említett, írott müfajok elemzéséböl azt a következtetést vonhatjuk le, hogy ezek a kommunikatív szituációk tudományos és szakmai szempontból lényegesek, hiszen számos információval szolgálnak ,a fordító láthatóságával, az ekvivalencia és az érthetőség kérdésével, a forrás- és célnyelvi kontextusokkal, [...] a fordítók és a fordítások szerepével, az etikai kérdésekkel, a fordítás és a soknyelvü kommunikáció témájával, valamint a fordítók, tolmácsok és a mediátorok közötti szakmai határvonallal kapcsolatban" (110-111).

A tanulmány kiválóan gyüjti egybe az egészségügyi vonatkozásokat is érintő krízisekkel összefüggő fordítási munka jellemzőit: ez a fajta munka nem a szokásos forrás- és célnyelvi nyelvhasználat és kultúra kontextusában megy végbe; ebben az egyirányú információáramlásban gyakran nincs is forrásnyelvi szöveg; az egészségügyi készültség és tevékenység része a krízissel összefüggő fordított szövegek megléte; a fordítás sok esetben müfaji átírást is jelent (pl. szakértői szövegek laikus felhasználók számára való fordítói átírása); a fordítások már nemcsak szakmabelieknek készülnek, hanem pl. magukban foglalnak laikusoknak szóló fordításokat is; új müfajok (pl. mobiltelefonos applikációk) fordításaira is szükség van; a fordításokban nagy szerepet kap a könnyü érthetőség és olvashatóság; egyre nagyobb szükség van digitális tartalmak fordítására; a fordításokra gyakran tömegkommunikációs célból, soknyelvü és multikulturális helyzetekben van szükség. A szerző szerint az eddig láthatatlanságba burkolózó fordítóknak nagyobb teret kellene kapniuk, hogy elmondhassák a szakma számára tapasztalataikat, és hogy ennek kapcsán még pontosabban ki lehessen jelölni e terület kutatási irányait. Montalt egyúttal speciális képzési programok kidolgozását is sürgeti.

A második rész Izabel Emilia Telles de Vasconcelos Souza által jegyzett második tanulmánya (címe: Intercultural Mediation in Healthcare: Thematic Analysis, from the Interpreters' Perspective) a szaktolmácsok lehetséges és - magas színvonalú egészségügyi szolgáltatásokat nyújtó kontextusokban megnyilvánuló - ideális szerepeit taglalja. A cikk arra keres választ, hogy a tolmácsok nyelvi és kulturális szempontból egyaránt mediáló tevékenységet végeznek-e, amennyiben tevékenységük egészségügyi területhez kapcsolódik, valamint hogy a jó minőségü egészségügyi ellátásra negatív hatást gyakorolnak-e az interkulturális kommunikáció során megnyilvánuló kulturális különbségek. A szerző ennek elemzésére 2011 és 2015 között felvett adatokat használ: ezek forrása egyrészt 5 ország 18 egészségügyi tolmácsával készült interjúk, valamint egy 25 ország 423 egészségügyi tolmácsa által megválaszolt, online kitöltésủ kérdőív. A kutatás során specializált szakmai végzettséggel rendelkező adatközlőket kértek arra, hogy értékeljék az interkulturális mediáció alkalmazásának előnyeit és hátrányait egészségügyi szolgáltatások igénybevételekor történő tolmácsolás esetén: miért alkalmaztak a tolmácsok mediációt a beteg és a személyzet közötti kommunikáció során, valamint e tevékenység kapcsán milyen nehézségeik voltak.

Az eredmények azt mutatják, hogy kulturális mediációt akkor használ a tolmács, ha meg akar győződni, hogy a beteg értette-e a tolmács által vele közölt információkat; amikor a tolmács a beteg félelmét és stressz-szintjét próbálja olda- 
ni a kommunikáció sikeressége érdekében; amikor a tolmács a beteg számára a kulturális befogadottság és tisztelet jeleit kívánja sugározni; amikor a tolmács a beteg kultúrájáról vagy általánosságban a kulturális befogadásról ad információt az egészségügyi dolgozóknak; amikor a tolmács egyben az egészségügyi ellátást nyújtó szakszemélyzet része; amikor a tolmács a beteg számára a biztonság érzetét kommunikálja; amikor a tolmács a beteg szakszemélyzettől való félelmét és az irántuk való bizalmatlanságát kívánja csökkenteni; valamint amikor a tolmács a beteg testi, mentális és szellemi jólétét kívánja elősegíteni. A tanulmány azt is leírja, hogy a kulturális mediációra gyakran nincs idő a tolmács munkája során, valamint hogy a mediációs tevékenység negatív következményekkel is járhat. Zárásképpen a cikk megállapítja, hogy manapság a jó színvonalú egészségügyi ellátás már nem várja el a betegektől, hogy kulturális szempontból igazodjanak a domináns kultúrához: ehelyett az a gyakorlat, hogy az egészségügyi intézmény kulturális értelemben kompetens személyzetet - beleértve ebbe szakképzett tolmácsokat - alkalmaz, akik képesek betegközpontú szemléletben gondolkodni, ehhez viszont nézőpont- és attitüdbeli elmozdulásra van szükség.

A második rész harmadik cikkében (cím: Interpreting for Refugees: Empathy and Activism) Marija Todorova egy macedóniai menekülttáborban dolgozó tolmácsok helyzetét és attitüdjét méri fel olyan emberi élethelyzetek kapcsán, amelyek erőszakos konfliktusok révén alakultak ki. A tanulmány abból a feltevésböl indul ki, hogy az ilyen élethelyzetek esetében a tolmácsok nem egyszerüen üzeneteket közvetítenek két nyelv viszonylatában, hanem aktív szerepet vállalnak az elesettek, így a menekültek védelmében is. A szerző ezt etnográfiai módszerrel lefolytatott interjúk során begyüjtött adatokkal igazolja: négy olyan tolmácsról tudunk meg információkat, akik menekülteket segítő humanitáriánus szervezeteknek dolgoznak Macedóniában. Marija Todorova szerint ehhez a munkához elengedhetetlen az empátia, amelyet Merlini és Gatti (2016) alapján a következőképpen definiál: „olyan szemléletmód felvételének a képessége, amelyben benne foglaltatik: az adott személy saját maga és a másik személy iránt megmutatkozó tudatos hozzáállás [...]; a másik élethelyzetének megértése; a másik iránti érdeklődés és elköteleződés bizonyos foka, amelyet az illető az érzelmek megjelenítésének segítségével [...] kommunikál" (154).

Az etikai és érzelmi összefüggések rövid tárgyalása mellett a tanulmány az empátia több tudományterületen (pszichológia, béketeremtés, aktivizmus és kommunikáció) használt meghatározását ismerteti és köti a fordítási tevékenység jellemzőihez. Ezután több tolmács sajátosságait elemezve a szerző felvázolja a közös tulajdonságokat. A cikk az ilyen helyzetekben tevékenykedő, ideális tolmács jellegzetességeit leírva megállapítja, hogy az ilyen tolmács olyan kulturális háttérrel bírjon, mint azok, akik számára tolmácsol; személyesen is empátiát érezzen azok iránt, akik számára tolmácsol; és megfelelő képzettséggel rendelkezzen. A szerző zárásként sürgeti az empátiának az aktivizmus, a konfliktusmegoldás és az egészségtudományok területén játszott szerepének kutatását, amely számos felfedezéssel kecsegtethet a fordítástudomány területén is. 
A második rész negyedik cikke (Voices of Refugee Doctors in the United Kingdom: An Exploration of Their Linguistic and Cultural Needs and Aspirations címen), amelyet Ceri Butler és Khetan Al Sharou szereznek, olyan külföldön szakirányú végzettséget szerzett, bevándorló hátterű orvosokról szól, akik az Egyesült Királyságban kívánnak munkát vállalni. A cikk ismerteti, hogy az angliai munkavállaláshoz milyen feltételeknek kell megfelelni és úgy találja, hogy a külföldi diplomával rendelkező orvosoknak ez kihívást és egyúttal pénzügyi nehézséget jelent. Az ilyen orvosok munkaerő-piaci integrációját három problémakör nehezíti: 1) az Egyesült Királyság egészségügyi ellátórendszerének nem kielégítő ismerte, amibe beletartozik az etikai és jogi vonatkozások hiányos ismerete, valamint az orvos-beteg kapcsolat és a beteg saját akaratának érvényesülését biztosító kérdések is; 2) az angol nyelv és kultúra kommunikációs és kulturális vetületeinek nem megfelelő ismerete, beleértve ebbe a nemverbális kifejezésekkel és a kulturális különbségekkel összefüggő tudáshiányt is; és 3) az angol nyelv olyan szintü ismerete, amely lehetővé teszi a betegekkel való hatékony és érthető kommunikációt anélkül, hogy az orvos eközben szakkifejezéseket vagy szó szerinti fordításokat használna.

A fenti tudáselemekben jelentkező hiányosságokra válaszul a szerzők képzési és támogatási programot alakítottak ki menekült hátterü orvosok számára: a tréning nyelvi és kulturális ismeretek átadását és az ezekkel kapcsolatos készségfejlesztést öleli fel. A képzésben 18 orvos és 2 fogorvos vett részt, akik 2-3 évvel korábban érkeztek az Egyesült Királyságba Szíriából, Afganisztánból, Pakisztánból és Irakból. A cikk részletesen mutatja be a 6 alkalmas képzést, amelyet a 2017/18-as tanévben hirdettek meg. A szerzők ezután leírják a résztvevőktől származó, a kurzus közepén és végén érkezett visszajelzéseket. Az adatok arra engednek következtetni, hogy még alaposabb kutatásokra van szükség annak azonosítására, hogy a menekült hátterü orvosok munkaerö-piaci integrálása milyen fejlesztési igényeket támaszt. A szerzők felhívják a figyelmet, hogy az egészségügyi szolgáltatóknak még nagyobb figyelmet kell fordítaniuk a kulturális különbségek azonosítására, valamint az azokkal kapcsolatos ismeretek átadására és a kapcsolódó készségek fejlesztésére.

A harmadik rész első tanulmányában (On France, Terrorism and the English Press: Examining the Impact of Style in the News) Ashley Riggs a retorikai eszközök használatát elemzi a brit sajtónak a 2016-os franciaországi terrorcselekményekről szóló tudósításaiban: azt vizsgálja, hogy a szöveg stílusa (azon belül a modalitás, tehát a feltételezések tényekként való bemutatása és az alliteráció) hogyan képes információt hordozni, illetve hogy hogyan fest le eseményeket és kultúrákat: tehát hogy e két eszköz miképpen képes keretezni a hírt. A szerző az újságírókat az ilyen jellegü híradások tekintetében kulturális mediátoroknak tekinti.

A tanulmány korpuszát a Guardian és a Telegraph - két ellentétes politikai irányultságú napilap - 27 újságcikke alkotja. A szerző azt vizsgálja, hogy a modalitás és az alliteráció hogyan járul hozzá a keretezéshez és az olvasók vonatkozásában az adott hírhez való hozzáállás kialakításához (pozícionálás). A szükséges politikai háttérismereteket is taglaló cikk arra a következtetésre jut, hogy elhanya- 
golhatónak tünő lexikai elemek is képesek alapvető hatással lenni az olvasóra és befolyásolhatják a szövegről és az annak tartalmáról alkotott képet.

A harmadik rész Maria Sidiropoulou által jegyzett második tanulmánya (címe: Re-Narrating Crisis: A Translation Perspective) a különbözö kultúrák krízisnarratíváinak különbségeit tárgyalja, és azt veszi górcső alá, hogy ezek hogyan hatnak a kultúrák katasztrófákhoz való viszonyulásához. A szerző azt elemzi, hogy valóban igaz-e, hogy az egyes kultúrák saját katasztrófareprezentációs mintákkal rendelkeznek, és hogy ezek a különbségek kulturális okokra vezethetők vissza (pl. hogyan szokás az egyes kultúrákban az elesetteket megjeleníteni). Kutatása kapcsán angolról görögre fordított, katasztrófákról szóló újságcímeket vizsgál, és ehhez két kutatási paradigmát egyesít: a retorikai szövegközpontú (rhetorical textoriented) és a stratégiai szövegközpontú (strategic or context-oriented) megközelítést használja a forrás- és célnyelvi cikkek elemzésére.

A korpuszt elemezve Maria Sidiropoulou a következö, görög nyelvben létező katasztrófatudósítási stratégiákat azonosítja: specifikus részletek megjelenítése, az esemény bizonyos jellemzőinek tompítása, az áldozatok állampolgárságának mellözése, és így a cikk olyan jellegü keretezése, amely az eseményeket globális hatókörben és érvényességgel jeleníti meg, valamint a felelősséget középpontba állító megfogalmazás használata. A tanulmány végkövetkeztetése, hogy a kríziskezelésnek tekintetbe kell(ene) vennie a katasztrófahelyzetekről szóló kommunikáció kultúrafüggő természetét is, és hogy ebből a szempontból a kríziskezelés támaszkodhatna a fordítástudomány ismereteire mind a kommunikáció, mind pedig a munkaerő (pl. fordítók) képzése szempontjából. A szerző úgy véli, hogy a fordítástudomány - a mostani kettővel szemben - a katasztrófakezelési ciklus mind a négy fázisához (kockázatcsökkentés és -enyhítés, készültség, reagálás és helyreállítás) érdemben tudna ismeretei révén hozzájárulni.

A harmadik rész harmadik cikkét (Emergenza Migranti: From Metaphor to Policy címmel) az egyik szerkesztő, Federico M. Federici jegyzi: a címben szereplő szókapcsolat olaszországi használatát elemzi abból a szempontból, hogy e szókapcsolatot hogyan használja fel az olasz média arra célra, hogy a menekültek által átélt humanitáriánus katasztrófát jelentéktelennek állítsa be. A tanulmány három elemzést integrál: 1) az emergenza migranti (menekültek okozta szükséghelyzet) olasz szókapcsolatnak az olaszországi médiában való használatát; 2) a hírek hitelességének elemzését, amely hitelességi deficit meggátol(hat)ja, hogy valódi párbeszéd alakuljon ki a migráció kérdéséről; és 3) a migrációval foglalkozó, eltorzított narratívák társadalmi hatását, amely az olasz társadalomban nem megfelelően funkcionáló interkulturális kommunikációban testesül meg, amely utóbbi ideális körülmények között segíthetné (vagy nem optimális esetben gátolhatja) a más nyelvü bevándorlók olaszországi integrációját. Az első elemzés az olasz média keretezési gyakorlatát világítja meg az emergenza szó kapcsán, amely valamifajta fenyegetést jelenít meg az események lehetőségként való kezelése és bemutatása helyett. A második elemzés az emergenza szó olasz sajtóban való elterjedését és a szóhoz kapcsolódó keretezés gyakorlatát vizsgálja. A harmadik elemzési pillér Bunn (2015) új 
cenzúrázási elméletére (New Censorship Theory) alapozva azt vizsgálja, hogy az olasz kormány és állam miképpen avatkozik bele a média müködésébe.

A cikk felveti az olasz média hitelességének és az abban zajló manipulációnak a kérdését is. Az olasz példán keresztül a szerző amellett érvel, hogy a média pusztán eszköz a politika három lépésben megvalósuló céljai számára: Federico M. Federici úgy véli, hogy a) elöször politikai célú narratívát teremtenek, b) ezt követi az ilyen narratívák újságírók általi újra és újra történő felelevenítése és újranarrálása, végül pedig c) az erre épülö nagypolitika és jogalkotás teljesíti be a valós politikai célokat. A migráció hatásaival és az ezen hatások kommunikációjával összefüggő kérdések kapcsán a szerző úgy véli, hogy Olaszországnak jelen helyzetben fokozottabban van szüksége interkulturális mediátorokra, fordítókra és fordításokra, akiket az olaszországi szociokulturális változások tesznek igazán nélkülözhetetlenné. Ezzel szemben viszont az olasz hatóságok és állam - ezen szükségletet tagadva - úgy tekint a migrációra, mint valamifajta szükséghelyzetre és így szem elől téveszti a valós interkulturális párbeszéd kínálta lehetőségeket.

Recenziónkat összegezve elmondható, hogy a kiadványt minden olyan diák, kutató és oktató haszonnal forgathatja, aki érdeklődik a fordítás, a tolmácsolás és a mediáció interkulturális vetületei iránt; különösen igaz ez az olyan helyzetek és események kutatása kapcsán, amikor az ilyen jellegü nyelvi közvetítés globális vagy helyi krízishelyzetekben érintett hátrányos csoportokat érint. Véleményem szerint a cikkek a maguk területén úttörő munkának számítanak. Többek között ezért is meggyőződésem, hogy az ismertetett esettanulmányok inspirálólag fognak hatni a magyar kutatókra is, és arra sarkallják majd őket, hogy hasonló vizsgálódásokat kezdjenek. Ha ez így lesz, akkor idővel a magyar fordításkutatók a könyvben bemutatottakhoz hasonlóan képesek lesznek még tartalmasabb módon hozzájárulni magyarországi esetleges konfliktusok és katasztrófák idején az interkulturális nyelvi közvetítést is megkövetelö kríziskezeléshez.

\section{Irodalom}

Baker, M. 2006. Translation and Conflict. A narrative account. London and New York: Routledge.

Baker, M. 2010. Resisting State Terror: Theorizing Communities of Activist Translators and Interpreters. In: Bielsa, E., Highes, C. (eds) Globalization, Political Violence and Translation. Basingstroke and New York: Palgrave Macmillan. 222-240.

Bunn, M. 2015. Reimagining Repression: New Censorship Theory and After. History and Theory 54. évf. 25-44.

Merlini, R., Gatti, M. 2016. Empathy in Healthcare Interpreting: Going beyond the Notion of Role. The Interpreters' Newsletter 20. évf. 139-160.

Taronna, A. 2015. La mediazione liguistica come pratica di negoziazione, risistenta, attivismo e ospitalità sulle sponde del Mediterraneo [Az alku, az ellenállás, az aktivizmus és a vendégszeretet eszközeként funkcionáló nyelvi mediáció használata a földközi-tengeri régióban]. Lingue e Linguaggi 16. évf. 159-175. 